\title{
APPLICATION OF MT AND GRAVITY METHOD TO POTENTIAL ANALYSIS OF KEPAHIANG GEOTHERMAL, BENGKULU
}

\author{
Boko Nurdiyanto \\ Upstream Technology Center \\ PT Pertamina \\ Jakarta, Indonesia \\ boko.suwardi@pertamina.com
}

\author{
Yunus Daud \\ Post Graduate Program of \\ Geophysics Reservoar \\ FMIPA, UI \\ Jakarta, Indonesia
}

\author{
Ahmad Zarkasyi \\ Center for Geological Resources \\ Geological Agency \\ Bandung, Indonesia
}

\begin{abstract}
An analysis of geothermal potential in KepahiangBengkulu area using gravity and MT measurements of PSDG has been done. The analysis was conducted on 286 gravity points and 37 MT points spread over the southern part of Mount Kaba to Babakan Bogor hot springs. Kepahiang geothermal system is related to the volcanic activity of Mount Kaba which is still preserving the residual heat from the magma. Based on the gravity residual anomaly, the structure that controls the emerging Sempiang hot springs is estimated to be Sempiang fault that in near north-south direction, while Babakan Bogor hot springs is estimated to be controlled by the Sumatra fault. The cap rocks scatter around Sempiang hot springs start from near ground surface with thickness of between 1500 meters to 2500 meters. Cap rock is a unit of Young Lava of Kaba with resistivity $<10 \mathrm{Ohm}-\mathrm{m}$ and density is $2.2 \mathrm{gr} / \mathrm{cm}^{3}$. Geothermal reservoir is estimated to be located under the cap rocks scatter around Sempiang hot springs as indicated by values of $10-60 \mathrm{Ohm}-\mathrm{m}$ in resistivity and density is $2.4 \mathrm{gr} / \mathrm{cm}^{3}$. The top of reservoir is estimated to be 1500 meters below the ground surface, these rocks are volcanic products of Old Kaba in form of either lava or pyroclastic. Kepahiang geothermal prospect area scatters $19 \mathrm{~km}^{2}$ wide around Sempiang hot springs which is bound by contrast resistivity and fault. It has potential geothermal of 133 MWe with the assumption of reservoir temperature (geochemistry) is $\mathbf{2 5 0}$ ${ }^{0} \mathrm{C}$. Calculation of geothermal potential is included in the classification of expected reserves, as well as the extent and thickness of reservoir rock and fluid physical parameters are estimated based on data integrated geosciences detail depicted in the model tentatively.
\end{abstract}

Keywords - Kepahiang Geothermal, Gravity, MT

\section{INTRODUCTION}

Geothermal energy is one of the environmentally friendly alternative energy. The total potential of geothermal energy in Indonesia is estimated at $27 \mathrm{GW}$, which is the largest geothermal potential in the world. Data compilation is carried out by the Ministry of Energy and Mines has identified no less than 256 geothermal prospect areas in Indonesia. Indonesian geothermal systems in the hydrothermal systems generally have high temperatures $\left(>225^{\circ} \mathrm{C}\right)$, only a few of them that have moderate temperatures $\left(125-225^{\circ} \mathrm{C}\right)$. So the potential for power generation in case undertaken [1]. But that has installed power capacity recently reached $1,200 \mathrm{MW}$, or about $4 \%$ of the existing potentials [2]. The problem faced is that most of the geothermal field can not be utilized due to the lack of technical data for characterization, so it can not attract investors for further development [2].

Geothermal field development requires a gradual process that is quite long and requires a substantial investment costs. Before the geothermal potential can be harnessed as a source of energy, there must be initial steps are done, a study to determine the character of the geothermal system in terms of geology, geophysics and hydrology, as well as estimates of stored energy reserves.

The purpose of this study was to determine the geothermal system, and calculate potential prospects based on MT and gravity data analysis in Kepahiang, Bengkulu.

\section{STUDY AREA}

\section{A. Regional Geological Setting}

Sumatra located along the southwestern edge of the continental Sunda plate and on the western edge of the Sunda arc, oceanic crust beneath tilted subducted towards the north northeast [3]. Subduction beneath the western edge of Sumatra was initiated at the beginning of Permian [3].

Regional fault system along Sumatra is a result of the subduction system, the pressure generated by the oblique collision between the Indian-Australian plate and the Eurasian plate appearances process becomes a means of geothermal resources in Sumatra associated with volcanoes. Figure 1 shows that the pattern of tectonic region as a whole is very complex and shows many asperities. There are four patterns of 
lineaments (fault) that can clearly be observed on radar image, ie: Pattern lineament (fault) Northwest-Southeast, Northeast-

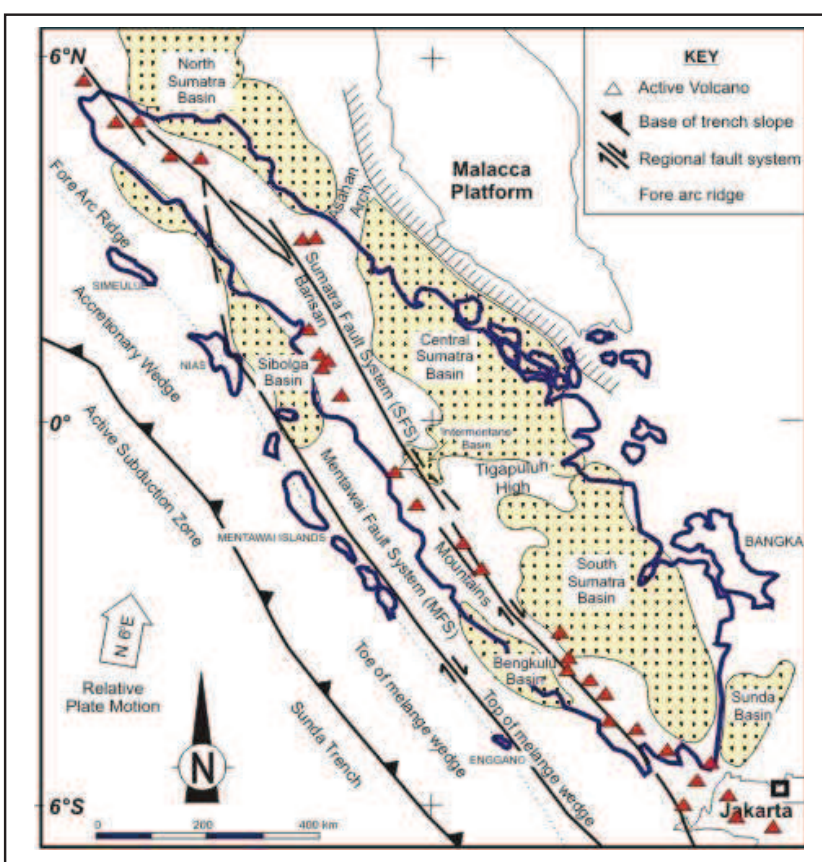

Figure 1. Regional tectonic Sumatra (Bengkulu Basin, [6])

Southwest, North-South and East-West. Fault structures trending Northeast-Southwest, namely: the Great Sumatran Fault Zone, especially those who are active in this area also shows the complexity of the structure of a fault zone termination [4]. Termination of this fault zone consists of many segments of the fault zone that forms the transtension zone and the step-over zone-compressional between fault segments [5].

\section{B. Manifestations of Kepahiang Geothermal}

Geological data of Kepahiang geothermal area indicate the presence of impermeable rock that has the properties of the clay mineral montmorillonite and kaolinite types, they are quite high in the area around the manifestation of Sempiang alteration, rock alteration that forms a type of argillic to advanced argillic. The alteration appears pyroclastic flows and lava of Mount Kaba products. The cap rock is in the Sempiang fault zone structures trending almost north south. In addition to the data alteration, other possibilities that can be interpreted as the cap rock is massive Young Kaba Lava and not yet strongly fractured [7].

Manifestations of the Kepahiang geothermal and the surrounding area (Figure 2) consists of fumaroles, solfatara, hot springs, rock alteration and craters accompanied by sublimation of sulfur that quite thick at the top of Mt. Kaba (temperature $96-360^{\circ} \mathrm{C}$ ). There are two groups manifestations, the first group is Sempiang group located at the headwaters Air Putih (Bukit Itam area), consisting of the appearance of the hot springs, fumaroles and rock alteration. The second group is Babakan Bogor group found in the Babakan Bogor village, manifestations such as appearance of 2 hot springs and cold springs [8].

The manifestations outside of the research area are hot springs in the northwestern part of the leg Mt. Kaba (Suban and Tempel Rejo hot springs), in the eastern part (Sindang Jati hot springs) and in the southern part (Bayung hot springs) [7].

Kusnadi [7] shows the hot water fumaroles of Kaba crater and Sempiang hot springs are sulfuric acid type, whereas Babakan Bogor 1, Bogor Babakan 2, Sindang Jati, Suban, Tempel Rejo, and Bayung hot springs are bicarbonate type. All of the hot springs in the immature zone water and interaction of the fluid with the rock in hot conditions, also mixed with surface water (meteoric water). Babakan Bogor 1 and Bogor Babakan 2 hot springs are no indication that the hot water interact with the volcanic system before it reaches the surface. Based on geotermometer gas shows reservoir temperatures estimated at $250^{\circ} \mathrm{C}$ [7].

\section{Methodology}

\section{A. Research Data}

Measurement data used in this study are land gravity and magnetotelluric. Geological and geochemical information were used for support the analysis of the potential of geothermal energy. Measurement data obtained from the results of land acquisitions carried out by the Center for Geological Resources (PSDG). Measuring point spread in the southern part of Bukit Kaba up to Babakan Bogor hot springs.

Gravity measurement as much as 286 points with spacing are approximately 250 meters, while the MT data by 37 points with the distance between the measurement are 1000 meters to 2000 meters. Coverage of research area are $9250 \times 8740$ meters (Figure 2).

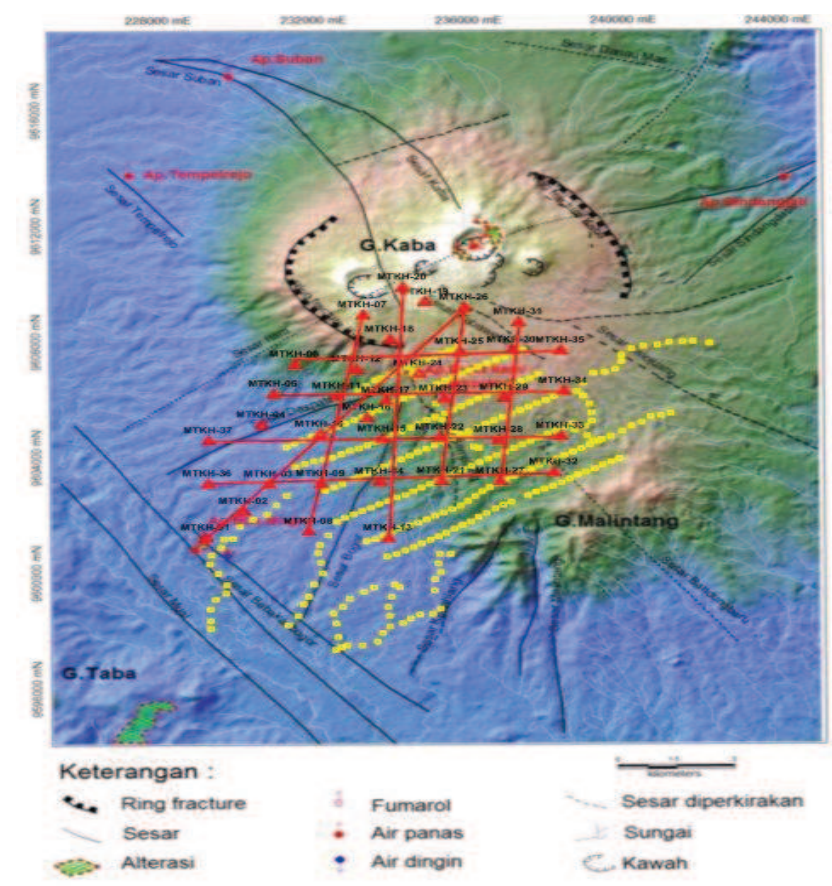


Figure 2. Red triangle are Gravity measurement points; Yellow box are MT measurement points and the red line is the line of 2D MT models

\section{B. Data Processing}

Gravity data processing is done to reduce the factors that affect the gravity data become complete Bouguer anomaly [9] [10]. To determination regional and residual anomalies using second orde polynomial method [11]. In a cross-sectional modeling the subsurface residual anomaly map created by Surfer software and GravPro-X. Calculation of depth estimation models using spectrum analyzer and to determine the type of geological structure using SVD analysis.

MT data processing begins with quality control data is done by looking at the time series of the electric field components (Ex, Ey) and magnetic field components $(\mathrm{Hx}, \mathrm{Hy}, \mathrm{Hz})$ of each measurement data from each station within a certain time interval, and then carried out the selection of data where there is no many distractions. Processing time series data [11] performed with SSMT 2000 and editing is done using MTEditor.

Static correction done using statistical averaging methods [12] [13] and 2D inversion modeling performed on the nine line. Four line in south-north direction, four line in east-west direction and one line in southwest-northeast direction that passes through the Babakan Bogor and Sempiang hot springs. $2 \mathrm{D}$ modeling is done by WinGLink and 3D visualization using GeoSlicer-X.

\section{RESUlts AND DiscUSSION}

\section{A. Gravity Methods}

Gravity observation value $\left(\mathrm{g}_{\mathrm{obs}}\right)$ in the base station is $977863.9776 \mathrm{mGal}$. The average value of the surface density (density topography) using Parasnis method [9] in the study area is $2.40 \mathrm{gr} / \mathrm{cm}^{3}$.

Figure 5 (top) shows the regional anomaly map with a range of values between 22 to $68 \mathrm{mGal}$. The pattern of high values anomalous in the middle with trending northeastsouthwest. Value rises in the middle because of rocks are arranged by the old volcanic rock that properties more massive, while in the southeast and northwest, anomalous values relatively decrease due to the rocks that arrange the area are young volcanic rocks.

Residual anomalies (Figure 5:bottom) shows alignment patterns contour between the low and high anomalies quite sharp. Range residual anomalous values ranging from -7 to 21 $\mathrm{mGal}$. The alignment patterns indicate that controlling fault structures or geothermal systems in the study area.

Alignment contour of high and low anomaly dominant trending northwest - southeast, it is interpreted as the main active fault structure of the Sumatra fault and is the structure that controls Babakan Bogor hot spring manifestation. The other is a alignment contour of high and low anomaly trending nearly north - south, this alignment indicates a fault structure trending. These fault is interpreted as structure that control Sempiang hot spring manifestation.

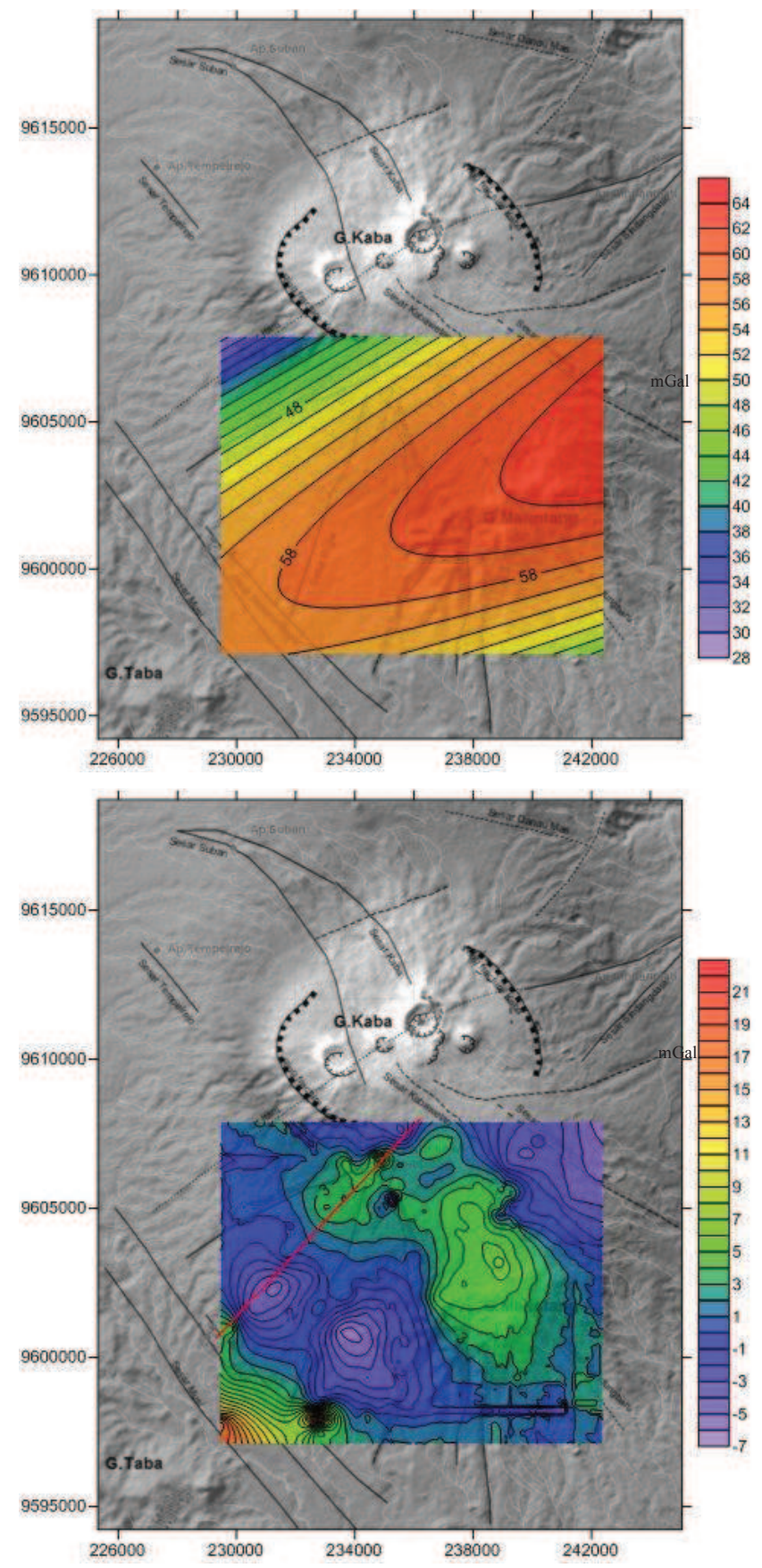

Figure 5. Map of regional anomaly (top) and residual anomaly map of Kepahiang geothermal area (bottom)

In calculating the estimated depth of the response by spectrum analysis on six line in the complete Bouguer anomaly contour. The estimated depth of the response to each line is $2178 \mathrm{~m}, 1905 \mathrm{~m}, 3511 \mathrm{~m}, 3282 \mathrm{~m}, 2604 \mathrm{~m}$ and $1737 \mathrm{~m}$, in order to obtain the average depth of response is used as model input cross section of the subsurface gravity method is 2500 meters. 
Second vertical derivative (SVD) of Bouguer anomaly was calculated by the Elkins method [15]. This method to determine the type of geological structures modeling. In determining the criteria for the type of fault structures using correlation $\left(\frac{\partial^{2} g}{\partial z^{2}}\right)_{\text {maks }}>\left|\frac{\partial^{2} g}{\partial z^{2}}\right|_{\min }$ for normal fault and $\left(\frac{\partial^{2} g}{\partial z^{2}}\right)_{\text {maks }}<\left|\frac{\partial^{2} g}{\partial z^{2}}\right|_{\min }$ for thrust fault. Two profiles that represent of the response of the geological structure are showed in figure 6, and based on existing criteria indicate that the anomalies are the normal fault.

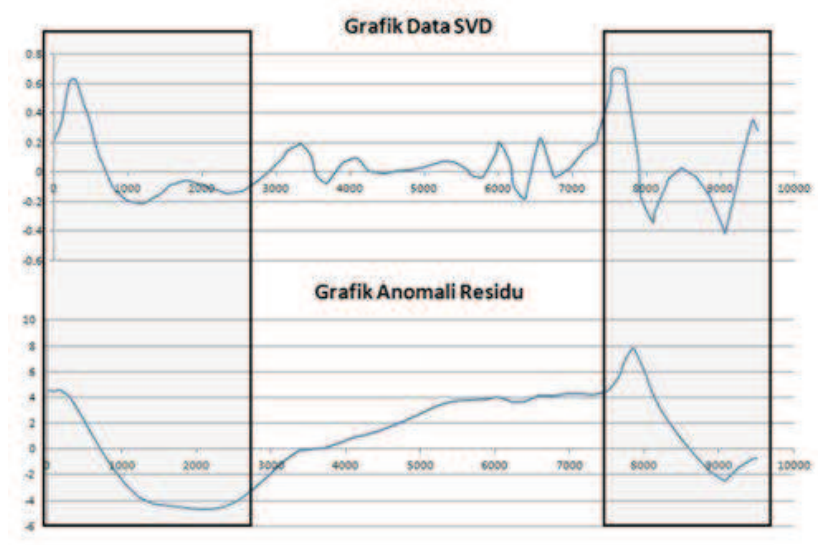

Figure 6. Graph of line A-A' for SVD (top) and residual anomaly data (below)

Inversion model of residual anomaly is also made using the Zondmag2D, the result (Figure 7) shows the variation of density between 1.94 to $2.88 \mathrm{gr} / \mathrm{cm}^{3}$ along the line $\mathrm{A}-\mathrm{A}^{\prime}$. The line trending southwest - northeast which is the alignment of the Babakan Bogor hot springs towards the Sempiang hot spring. In the southwestern and northeastern parts there has been density contrast represent a fault structures that control the appearance of the Babakan Bogor hot springs and Sempiang hot springs.

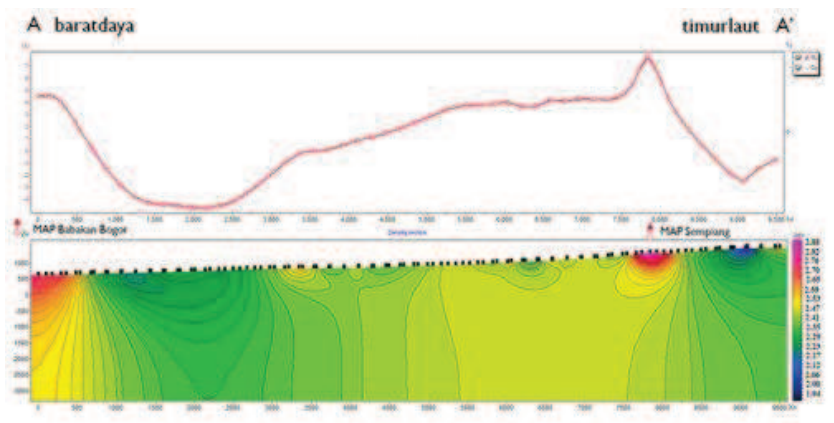

Figure 7. 2D cross-sectional model of gravity inversion results. Figure line A -A'as shown in Figure 5

Based on geological surface information, the results of spectral analysis, SVD analysis and 2D gravity inversion model, then made a cross section model of the subsurface structure. Figure 8 shows the subsurface modeling of the gravity with anomaly of topography density is $2.4 \mathrm{gr} / \mathrm{cm}^{3}$ in line $\mathrm{A}-\mathrm{A}$ '.

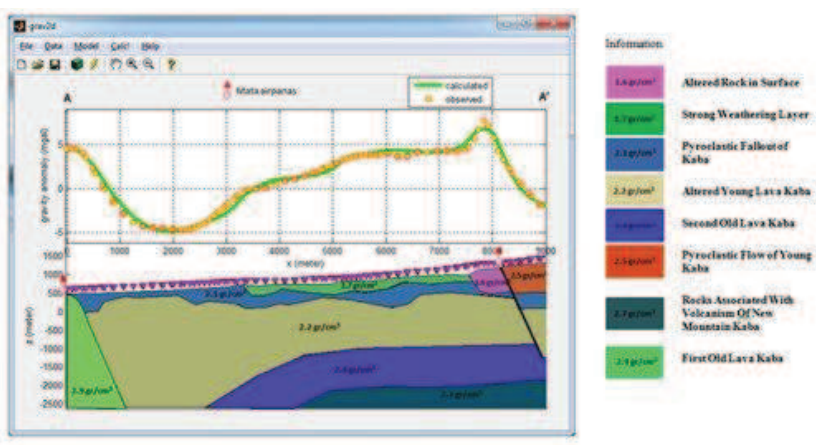

Figure 8. 2D cross-section model of gravity in Kepahiang geothermal area. Figure line A-A'as shown in Figure 5

A cross section models of Gravity shows geological structures, they are lithology contact and fault which are control the manifestation of Babakan Bogor and Sempiang hot spring. Rock density varies from 1.6 to $2.9 \mathrm{gr} / \mathrm{cm}^{3}$. In the early part of the line (southwestern) contained $2.9 \mathrm{gr} / \mathrm{cm}^{3}$ rock density that interpreted as Lava of First Old Kaba, then there is a lithological contact, below layer has a density of $2.2 \mathrm{gr} / \mathrm{cm}^{3}$ interpreted as Young Kaba Lava are undergoing process of alteration that has decreased in density value and upper layer is the pyroclastic fallout of Kaba $\left(2.1 \mathrm{gr} / \mathrm{cm}^{3}\right)$, and on the surface there is a layer that has undergone strong weathering with a density of $1.7 \mathrm{gr} / \mathrm{cm}^{3}$. Layer beneath the Young Kaba Lava there is a layer of Second Old Lava Kaba with density of 2.4 $\mathrm{gr} / \mathrm{cm}^{3}$, while the lowest density $(1.6 \mathrm{gr} / \mathrm{cm} 3)$ in the northeastern part of an area of geothermal manifestations are thought to be the location of the rock changes due to the influence of the activity of the Kepahiang geothermal system. In northeastern section there is pyroclastic flow of Young Kaba with density $2.5 \mathrm{gr} / \mathrm{cm}^{3}$, bounded by the fault that controls Sempiang hot spring. At the depth of 2000 meters there looks rock with a density of $2.7 \mathrm{gr} / \mathrm{cm}^{3}$, this rock are interpreted as lithologies related to volcanism of New Mount Kaba.

\section{B. MT Method}

2D resistivity model from MT measurement in Kepahiang geothermal area at 9 line that trending southwest-northeast, south-north and west-east (Figure 3) are shown in the vertical and horizontal cross-section to describe the distribution layer with low, medium and high resistivity.

2D resistivity model of line 1 (Figure 9) shows a distribution of low resistivity values extending from the southwest to the northeast. This low resistivity scattered from near the surface to 2500 meters depth with a thickness between 1500 to 2500 meters. Low resistivity are interpreted as the response of the rock alteration that serves as the cap rock geothermal system in this area. At the bottom of this layer, scattered moderate resistivity values. Resistivity that located between the Babakan Bogor hot springs and Sempiang hot springs are interpreted as a response of the geothermal reservoir, while the high resistivity values next to northeastern Sempiang hot springs are interpreted as a reservoir associated with the volcanism of Mount Kaba. 
In the cross-section of the Babakan Bogor hot springs and Sempiang hot springs seen the contrast of resistivity values are interpreted as an indication of lithological contacts and fault structures. Contrast resistivity values seen in the north-east, around the point MTKH-25, interpreted as an indication of the caldera structure located around the peak of Mount Kaba.

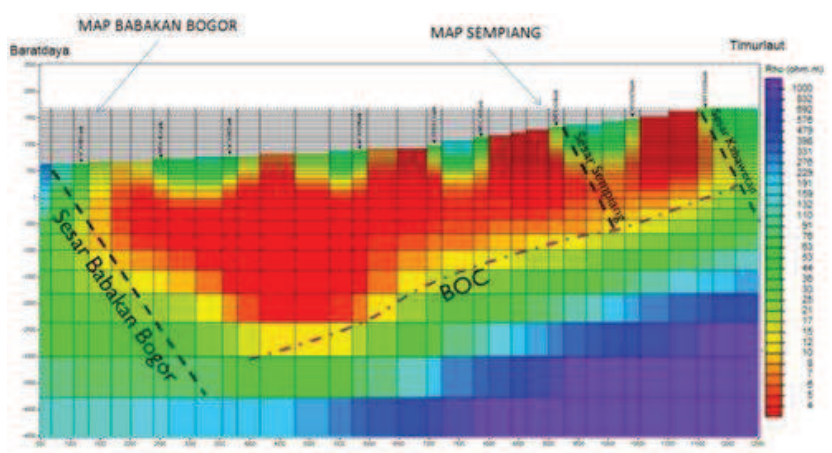

Figure 9. 2D resistivity model of the line 1

Figure 10 (top) is shown resistivity model of line 2-5 in the south - north direction and figure 10 (bottom) is shown resistivity model of line 6-9 in the west - east direction. Figure 11 shows the resistivity model results in a horizontal crosssection.

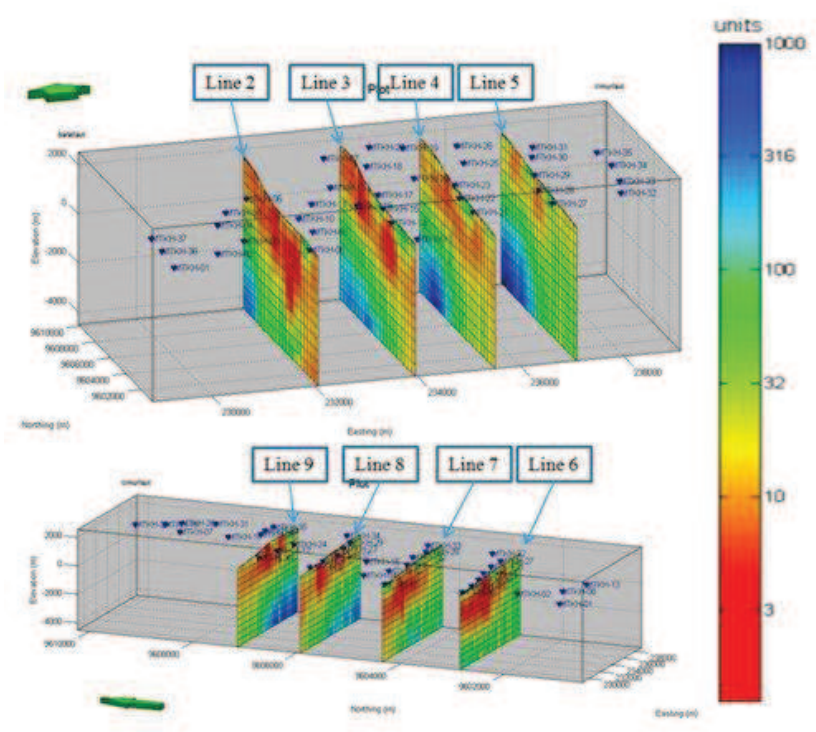

Figure 10. Resistivity model in a vertical cross-section

From Figure 10 and 11 clearly visible scatter of low resistivity $(<10 \mathrm{Ohm}-\mathrm{m})$ that extends from the southwest to the northeast. In the northeastern part of the low resistivity are spread from near the surface to a depth of about 1500 meters, towards the south-west of this low resistivity thicken up to 2500 meters. Low resistivity are interpreted as the response of the rock alteration that serves as the cap rock geothermal system.
At the bottom of this layer, scattered moderate resistivity values with depth following the thickness of the layers of cap rock. The resistivity are interpreted as a response of the geothermal reservoir. High resistivity values are in the northeast to form a dome with the top of the dome in the northeast of research area. These rocks are interpreted as volcanic rocks associated with the volcanism of Mount Kaba. Distribution of the cap rock, reservoirs and volcanic rock possibility still being towards the north of studied area (towards the top of Mount Kaba).

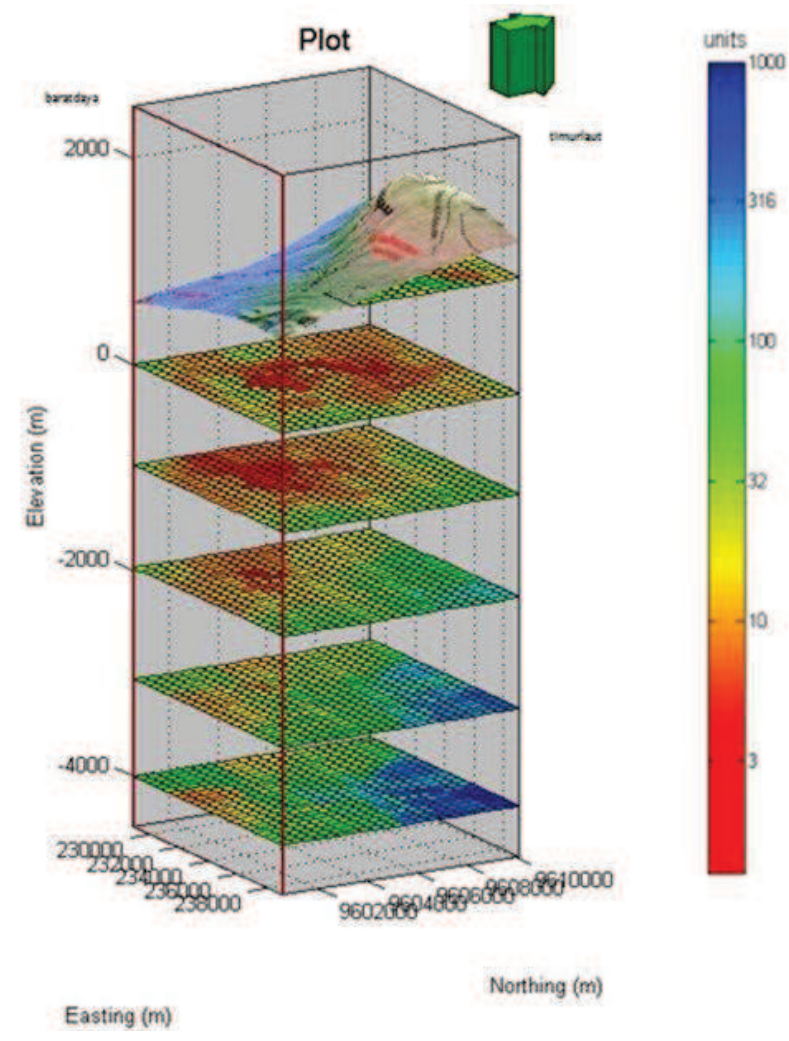

Figure 11. Resistivity model in a horizontal cross-section

\section{Kepahiang Geothermal Systems}

Formation of geothermal systems in Kepahiang particularly in the area of Kaba in the framework of plate tectonics is closely related to the magmatic arc path. Kepahiang geothermal system model is very similar to the model proposed by Bogie, et al. [16] is a model of volcanic geothermal systems (magma reservoir). Reservoir of geothermal system is a reservoir of hydrothermal system, ie where the geothermal reservoir system containing steam, water or a mixture of both, depending on reservoir pressure and temperature [17].

These systems are thought to form due to the interaction of tectonic plates stretch of rock that is as thick as $64-145 \mathrm{~km}$ which floats on the asthenosphere. These plates move slowly and constantly push each other and one of them will subducted under the other plate. Because of the heat in the astenosfere and heat due to friction, the tip of the slab crushed melt, has a high temperature (magmatism process). The existence of this hot 
rock causes the temperature gradient in the area to be larger than the average gradient temperature.

As a result of the subduction system, pressure or compression produced by the oblique collision between the Indian-Australian plate and the Eurasian plate resulted in regional fault that extends along the island of Sumatra, which is a means for the emergence of geothermal sources associated with young volcanoes. According Saptadji [1] also concluded that geothermal systems in Sumatra are generally controlled by regional fault systems associated with the Sumatra fault system. Sumatra geothermal reservoirs in sedimentary rocks which generally occupy has undergone several tectonic deformation or faulting at least since the Tertiary until Resen. This led to the formation of secondary porosity or permeability in sedimentary rocks are dominant in the end produces geothermal reservoir permeability is large. Judging from the characteristics of the geothermal system has a high enough temperature associated with young volcanic activity.

Geothermal fluid contained in the hydrothermal reservoir comes from surface water, among other rainwater (meteoric water) that penetrate the bottom surface of the slopes of Mount Kaba and from outside the Kaba complex area, and heated by a heat source. The water will enter through cracks into the permeable rock. The surrounding rocks are the source of heat from magma, then the heat will be propagated through the rock (by conduction) and through the fluid (by convection). Heat transfer by convection occurs basically due to the buoyant force (bouyancy). Water because of gravity always has a tendency to move down, but if the water is in contact with a heat source, there will be heat transfer to the water temperature becomes higher and the water becomes lighter. This situation causes more hot water moving upward and cooler water moves down to the bottom, resulting in water circulation or convection currents.

Rocks in hydrothermal systems is a natural rock fracturing. In the study area there is a geological fault structure which allows the water to flow through cracks and or permeable rock, and then appeared on the surface. Phase change occurs on its way to the surface, when the water temperature has reached the saturation temperature or the temperature of the boiling point. So that the fluid in the form of steam-water mixture and form a vapor phase only. This leads to the types of geothermal surface manifestation became very diverse, there are hot springs, fumaroles, cold springs and rock alteration that each has different characteristics despite its close proximity.

By looking at the manifestations of hot springs, fumaroles and alteration (acid) in the area Sempiang hot springs estimated as the upflow of geothermal systems Mount Kaba, while Babakan Bogor, Suban, Tempel rejo, Sindang Jati hot springs on the bottom slopes of Mount Kaba estimated is outflow zone of the geothermal system Mount Kaba (Geochemistry).

Heat source on Mount Kaba geothermal system associated with Quaternary volcanic system that still has a heat content and complex active volcano Mount Kaba is type A. History of the volcanic eruption of Mount Kaba has experienced in 1951 and the formation of the crater Volkgesang (Directorate of
Volcanology, 1990) and in 2004 a hydrothermal eruption (freatomagmatik) at Kaba large crater. Based on these data, the heat source in this system is estimated to originate from volcanism of New Kaba Mountain product.

The cap rock is estimated to be rock alteration and Young Kaba Mountain product that has not undergone fractured and alteration process (density $2.2 \mathrm{gr} / \mathrm{cm} 3$ ). This alteration of rocks have different physical properties that are not unchangeable rocks, one of which is the resistivity of rocks. In geothermal systems in volcanic areas, rock alteration that serves as the cap rocks generally give low resistivity value of the response, while the rock which serves as a reservoir to respond resistivity values higher than the cap rock. Based on the results of MT in Kepahiang geothermal area, low resistivity values $(<10 \mathrm{Ohm}-$ $\mathrm{m}$ ) is interpreted as the response of the rock alteration (the cap rock) scattered around the Sempiang hot springs and dilated toward Babakan Bogor hot springs. This low resistivity began to spread near the surface of the soil to a depth of about 2500 meters with a thickness of between 1500 meters to 2500 meters (Figure 12).

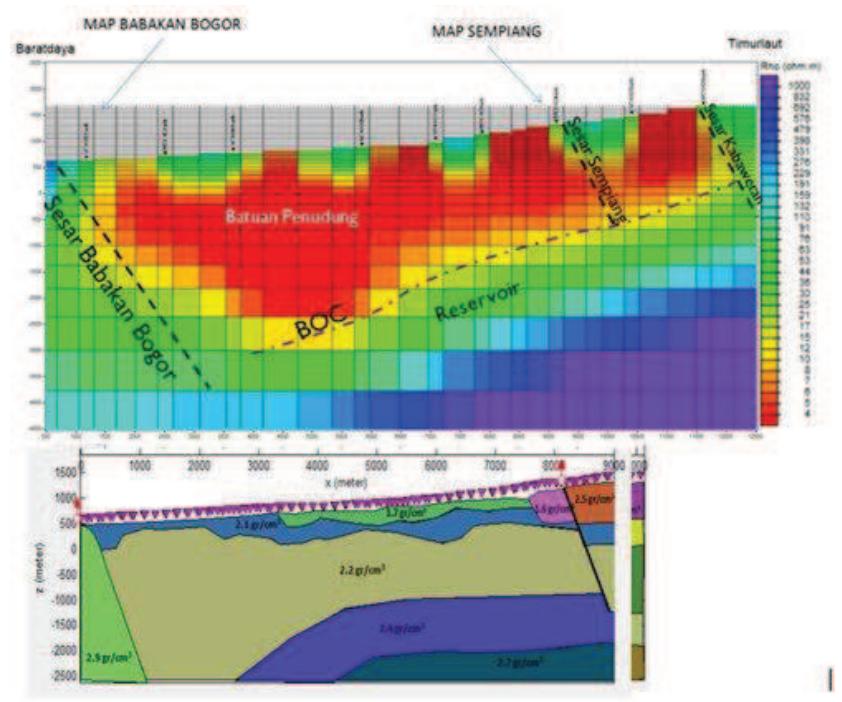

Figure 12. Subsurface cross section model based on gravity and MT method

Geothermal reservoir is estimated to be under the rock alteration as indicated by resistivity values between 10-60 Ohm-m and density $2.4 \mathrm{gr} / \mathrm{cm}^{3}$ scattered around the Sempiang hot springs and dilated toward Babakan Bogor hot springs. The highlight of the reservoir is estimated to be in the north Sempiang hot springs with a depth of about 1500 meters below the ground surface. Based on geological data, this rock is a product of the Old Kaba Volcanic lava or pyroclastic.

From the results of 3D visualization based on the resistivity model (Fig. 13) and the gravity model and supported by geological and geochemical information, and then made a conceptual model of the Kepahiang geothermal system (Figure 14). Conceptual image of the model can be explained that the Sempiang hot springs is upflow zone and Babakan Bogor hot springs is outflow zone. So the geothermal prospect areas located around Sempiang hot springs. 


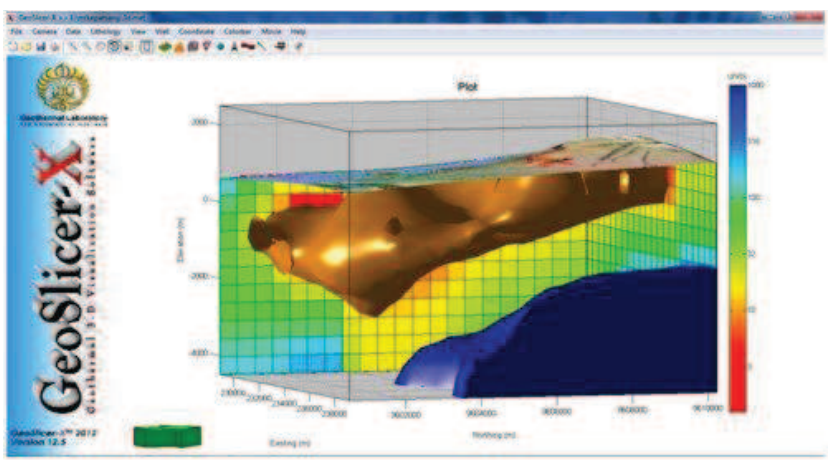

Figure 13. 3D visualization results based on resistivity models using GeoSlicer-X

\section{Prospect area of Kepahiang Geothermal}

By considering the geochemical and geological data, from the processing of gravity and MT is then used to determine the prospect areas of Kepahiang geothermal. The area is localized using the base of conductor map (BOC) which is the lower limit of the cap layers so the distribution of reservoir can be determined. The prospect area of Kepahiang geothermal that calculated from BOC which bounded by fault and depth of BOC is $19 \mathrm{~km}^{2}$ (Figure 15).

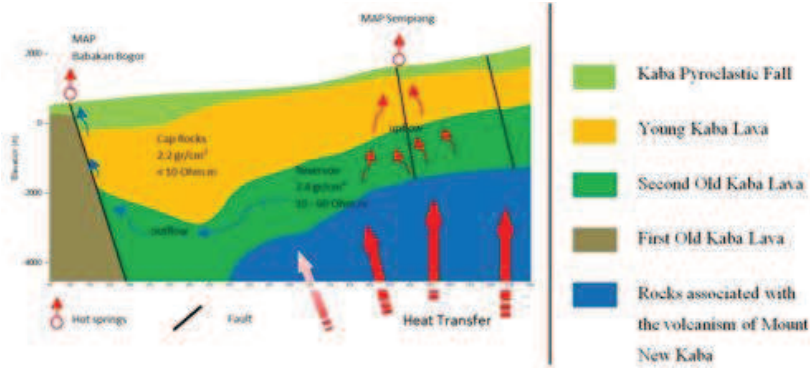

Figure 14. Conceptual model of Kepahiang geothermal system by gravity and MT methods

Calculation of the geothermal energy potential uses the basic principles of volumetric methods, geothermal reservoir is considered as a form of a box whose volume can be calculated by multiplying the widespread distribution and thickness. The approach model used was lumped parameter models that assume a uniform reservoar parameters [18].

Volumetric method used in the resource class hypothetical until proven. Some assumptions are needed to estimate the heat energy equal to the electrical energy. Assumptions used: $1 \mathrm{~km}$ thick reservoir, recovery factor $=50 \%$, conversion factor $=$ $10 \%$, lifetime $=30$ years.

Lump parameters equation:

$$
Q=K x \boldsymbol{A} x \text { (Tres }- \text { Tcut off) }
$$

Where $\mathrm{K}=0.1$ (conversion factor for thermal energy contained in the thermal fluid) and $\mathrm{K}=0.19$ (for the heat energy contained in the fluid and rock formations), $\mathrm{A}=$ area of the prospect; Tres = reservoir temperature; tcut off $=$ temperature cut-off

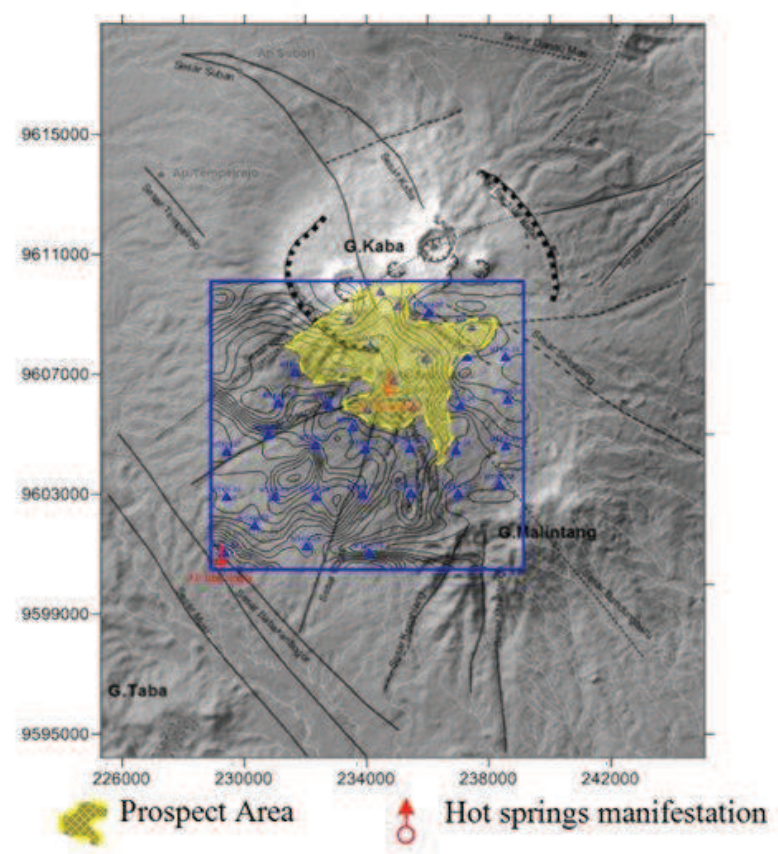

Figure 15. Prospect area map of Kepahiang geothermal

Information based on geology, geochemistry and geophysics, geothermal prospect areas in the study area is as shown in Figure 5.5. Kepahiang geothermal prospect areas are around the Sempiang hot springs bounded by contrasting resistivity and geological structure has a $19 \mathrm{~km}^{2}$ area. Reservoir temperature based on geochemical analysis is $250{ }^{\circ} \mathrm{C}$, based on SNI classification is a high-temperature reservoir classification $\left(>225^{\circ} \mathrm{C}\right)$ so the temperature cut-off used $180^{\circ} \mathrm{C}[18]$ and $\mathrm{K}$ is used 0.1 then the area of Kepahiang geothermal energy potential is calculated as follows,

$$
\mathrm{Q}=0,1 \times 19 \times(250-180)=133 \text { Mwe }
$$

Kepahiang geothermal area with approximately $19 \mathrm{~km}^{2}$ prospect area has a geothermal potential of 133 MWe. Based on ISO Classification Geothermal Energy Potential in Indonesia in 1999, the calculation of potential geothermal reserves are included in the expected reserves classification, the extent and thickness of reservoir rock and fluid physical parameters are estimated based on data integrated geoscience described in detail tentative models [18].

\section{CONCLUSION}

The results of the Kepahiang geothermal system analysis based on analysis of gravity and MT as well as geological and geochemical information can be summarized as follows:

1. Kepahiang geothermal system in a volcanic geothermal system associated with Quaternary volcanic system with a heat source in this system is estimated to originate from volcanism of New Kaba Mountain product. 
2. Based on the residual gravity anomalies, structures that control the appearance of the hot springs in the area Sempiang estimated Sempiang fault trending nearly north-south. While the Babakan Bogor hot springs is estimated controlled by the Sumatra fault.

3. The cap rocks scattered around the Sempiang hot springs and widened towards the Babakan Bogor hot springs, starting near the ground surface to a depth of about 2500 meters with a thickness of between 1500 meters to 2500 meters. The cap rock is a unit of the altered Young Kaba Lava with resistivity values $<10 \mathrm{Ohm}-\mathrm{m}$ and density 2.2 $\mathrm{gr} / \mathrm{cm}^{3}$.

4. Geothermal reservoir is estimated to be under the cap rocks as indicated by resistivity values between 10-60 Ohm-m and density $2.4 \mathrm{gr} / \mathrm{cm}^{3}$. Volcanic rock is a product of the Old Kaba either lava or pyroclastic.

5. Kepahiang geothermal prospect area scatters $19 \mathrm{~km}^{2}$ wide around Sempiang hot springs which is bound by contrast resistivity and fault. It has potential geothermal of 133 MWe with the assumption of reservoir temperatur (geochemistry) is $250{ }^{\circ} \mathrm{C}$.

6. Calculation of potential geothermal reserves is included in the classification of expected reserves, the extent and thickness of reservoir rock and fluid physical parameters are estimated based on data of integrated geoscience detail depicted in the tentative models.

\section{ACKNOWLEDGMENT}

The first author is very grateful to the Center for Geological Resources (Geological Agency) for providing the Gravity and MT data. Also, the author would like to thank the PT NewQuest Geotechnology for facilitating the data processing.

\section{REFERENCES}

[1] Saptadji, N.M., 2009. Karakterisasi Reservoir Panas Bumi. Training "Advanced Geothermal Reservoir Engineering, 6 - 17 Jumi 2009. ITB

[2] Tjahjono, B.S.E., Arsadi, E.M., Syuhada dan Arifin, J. 2010. Penyelidikan Geologi dan Geofisika untuk Inventarisasi Potensi Panasbumi di Kabupaten Rejang Lebong, Bengkulu. Laporan Akhir Tahun 2010 Kegiatan Program Insentif Bagi Peneliti dan Perekayasa, Lembaga Ilmu Pengetahuan Indonesia
[3] Gafoer, S., Amin, T. C., and Pardede, R., 1992. Geologi Lembar Bengkulu, Sumatra. Puslitbang Geologi, Bandung. 91 halaman

[4] Natawidjaja dan Sieh, 1994. Neotektonik dari sistem sesar Sumatra, Prosiding hasil-hasil penelitian puslitbang geoteknologi LIPI 1994. LIPI, Bandung

[5] Natawidjaja dan Ruslan, 1994. Kondisi Tektonik Serta Hubungannya dengan Kegempaan dan Aktivitas Gunung Api Di Daerah Rejang Lebong, Bengkulu. Prosiding hasil-hasil penelitian puslitbang geoteknologi LIPI 1994. LIPI, Bandung

[6] IAGI, 2009. Cekungan Bengkulu, diakses pada tanggal 16 April 2012. http://geologi.iagi.or.id/2009/03/22/cekungan-bengkulu/

[7] Kusnadi, D., Nurhadi, M., Suparman. 2011. Penyelidikan Terpadu Geologi dan Geokimia Daerah Panas Bumi Kepahiang, Kabupaten Kepahiang, Bengkulu. Prosiding Hasil Kegiatan Pusat Sumber Daya Geologi Tahun 2010. PSDG, Bandung

[8] Arsadipura, S., Kholid, M., Djukardi, D. 2011. Penyelidikan Geofisika Terpadu Gaya Berat, Geomagnet dan Geolistrik Daerah Panas Bumi Kepahiang, Kecamatan Kaba Wetan, Kabupaten Kepahiang, Provinsi Bengkulu. Prosiding Hasil Kegiatan Pusat Sumber Daya Geologi Tahun 2010. PSDG, Bandung

[9] Telford, W. M., Geldart, L.P., Sheriff, R.E., Keys D.A., 1990. Applied Geophysics 2nd edition. Cambridge University Press.

[10] Blakely, R. J., 1995, Potential Theory in Gravity and Magnetic Applications, Cambridge University Press.

[11] Purnomo, J., Koesuma, S., Yunianto, Y., 2013. Pemisahan Anomali Regional-Residual pada Metode Gravitasi Menggunakan Metode Moving Average, Polynomial dan Inversion. Indonesian Journal of Applied Physics (2013) Vol.3 No.1 halaman 10

[12] Vozoff, K., 1991, The Magnetotellruic Method, Chapter 8, Electromagnetic method in applied geophysics-Applications part A and part B, edit by Corbett, J.D., published by Scociety of Exploration Geophysicists, p.641-711.

[13] Sulistyo, A. 2011. Koreksi Pergeseran Statik Data Magnetotelluric (MT) Menggunakan Metode Geostatistik, Perata-rataan, Dan Time Domain Electromagnetic. Skripsi Program Studi Fisika, FMIPA, UI

[14] Jiracek, G.R. 1985. Near Surface and Topografic Distortion In Electromagnetic Induction. San Diego State University

[15] Elkins, T.A., 1951, The Second Derivative Method of Gravity Interpretation. Geophysics, 16, 29-50

[16] Bogie I., Lawless J.V., Rychagov S. and Belousov V. 2005. MagmaticRelated Hydrothermal Systems: Classification of the types of geothermal systems and their ore mineralisation. Geothermal and mineral resources of modern volcanism areas (proceedings of the International KurilKamchatka field workshop, July 16 - August 6, 2005), Publishing house ÖTTISK"', 2005. 460p

[17] Edwards, L. M., Chilingar, G. V., Rieke, H. H., and Fertl, W. H Handbook of Geothermal Energy, Gulf Publishing Company, 1982, Chapter 2

[18] Badan Standarisasi Nasional-BSN, 1999. Metode Estimasi Potensi Energi Panas Bumi. Standar Nasional Indonesia, SNI 13-6171-1999, ICS 73.020 